\title{
Coffee, Tea and Cancer
}

\author{
Hilal Harman (1)
}

\section{COFFEE}

Coffee, one of the most widely consumed drinks in the world, is obtained by roasting and brewing coffee beans. Coffee is a complex beverage containing more than a thousand active compounds, including caffeine (a strong central nervous system stimulant and bronchodilator), diterpene alcohols (serum cholesterol stimulant) and chlorogenic acid. ${ }^{[1]}$

\section{CAFFEINE}

Caffeine (1, 3, 7-trimethylxanthine) is the most sought-after substance in coffee compounds, an alkaloid found naturally in coffee beans. The half-life of caffeine is about 4-6 hours. ${ }^{[2]}$ Caffeine is rapidly absorbed in the digestive tract after digestion. After 90 minutes of caffeine consumption, serum caffeine concentration reaches the highest value. Caffeine is metabolized by the liver cytochrome P450 1A2 (CYP1A2) enzyme, and the difference in caffeine response of individuals is based on genetic polymorphism in the CYP1A2 gene. ${ }^{[3]}$

The amount of caffeine in coffee; type of coffee, the degree of roasting, cooking method can vary. A standard cup of coffee is thought to contain $100 \mathrm{mg}$ of caffeine. It was found that the amount of caffeine

Department of Nutrition and Dietetics, Istanbul Gelişim University, Istanbul, Turkey

Correspondence: Hilal Harman. İstanbul Gelişim Üniversitesi, Beslenme ve Diyetetik Bölümü, 34310 Avcılar, İstanbul, Türkiye.

Cite this article as: Harman H. Coffee, Tea and Cancer. JEB Med Sci 2020;1(2):75-78.

doi: 10.5606/jebms.2020.75616

Received : October 10, 2019

Accepted : August 20, 2020

Published online : November 09, 2020

(2)20 Journal of Experimental and Basic Medical Sciences. All rights reserved.

\begin{abstract}
Coffee and tea are the most consumed drinks in the world. Coffee has health effects with caffeine, diterpene alcohols and chlorogenic acid while tea with polyphenolic compounds Although epidemiological studies have shown that coffee and tea consumption potentially adversely affects health, recent studies have shown that it is effective in reducing the risk of some chronic diseases, especially cancer. The anticarcinogenic effects of coffee and tea have been found to be due to mechanisms such as reducing inflammation with antioxidant properties, taking part in the repair of DNA damage and modulating the immune process. However, there are few studies examining the relationship between cancer, tea and coffee, and the fact that these studies have been performed with different types of cancer leads to different results.

Keywords: Adverse effects, anticarcinogenic effects, coffee.
\end{abstract}

in $240 \mathrm{~mL}$ brewed 14 different coffees taken from coffee selling places in the USA varied between 72-130 mg. ${ }^{[4]}$ It was observed that the caffeine content in the same type $240 \mathrm{ml}$ coffee purchased from the same store on 6 different days ranged from $130-282 \mathrm{mg} \cdot{ }^{[5]}$ Although coffee production is carried out to certain standards, the caffeine content of coffees may vary. ${ }^{[2]}$ The average daily caffeine intake in the USA was found to be 106-170 mg. ${ }^{[6]}$ According to the Canadian Chemical Safety Bureau, daily caffeine intake should be limited to $400-450 \mathrm{mg} \cdot{ }^{[7]}$ Although it causes a moderate addiction, caffeine is generally included in the reliable component (GRAS) by the Food and Food Association (FDA) ${ }^{[8]}$

\section{DITERPENE ALCOHOLS}

Other compounds expressed as diterpene alcohols in coffee are cafestol and kahweol. These compounds, which are thought to be the main cholesterol-increasing factors in coffee, were found to be higher in boiled coffee types (such as Turkish coffee or Scandinavian coffee) than those consumed by pouring them into hot water. ${ }^{[9]}$ In a meta-analysis 
where the effect of coffee consumption on serum cholesterol concentration was investigated, it was found that boiled coffee consumption increased LDL and total cholesterol levels in serum compared to filter coffee consumption depending on the amount. ${ }^{[10]}$

\section{CHLOROGENIC ACID}

Chlorogenic acid, which forms antioxidant properties in coffee, is the most important polyphenol in coffee. ${ }^{[1]}$ In addition to its antioxidant properties, it exhibits antibacterial and anticarcinogenic effects. ${ }^{[12,13]}$ A single serving of coffee contains between 20 and $675 \mathrm{mg}$ of chlorogenic acid, depending on the time of roasting and the amount consumed. ${ }^{[14]}$

\section{COFFEE AND CANCER}

Cancer develops as a result of hereditary and/ or individual factors along with environmental factors, and the incidence of the disease increases significantly with age. The environmental determinants of cancer risk are diet, alcohol consumption, physical activity, obesity and stress. ${ }^{[15]}$ Experimental data show that coffee can potentially interfere with and/or have adverse effects on many steps in the cancer process. ${ }^{[16]}$

The protective effect of coffee in cancer is expressed by its antioxidant properties, mechanisms involved in DNA damage repair, modulating the immune process and reducing inflammation. ${ }^{[15-18]}$ There are studies suggesting that coffee is protective against cancer, as well as studies advocating that it has no cancer-related effects. ${ }^{[2,17-20]}$

In a 2007 report of a study by the World Cancer Research Fund (WCRF), there was an insignificant inverse relationship between a cup of coffee consumed once a day and the risk of breast cancer, while in some subtypes of breast cancer (type 1 mutation) In postmenopausal women, this relationship has been shown to be negatively significant in those treated with tamoxifen. ${ }^{[21-23]}$

Shimazu et al. ${ }^{[24]}$ showed that 90,000 female and male Japanese individuals followed for 10 years had $76 \%$ less risk of hepatocellular carcinoma than those who consumed 5 cups or more of coffee per day than those who did not consume coffee. Recent data show that caffeinated coffee consumption is necessary to see these beneficial effects. ${ }^{[25]}$

Another possible health benefit of coffee is that it reduces the risk of endometrial cancer. In a case control study, it was found that those who consume
1-2 cups of coffee per day and those who consume 3 cups or more of coffee per day are less at risk. ${ }^{[3]}$

In the case-control studies evaluating the relationship between colorectal cancer risk and coffee consumption, no linear relationship was found regarding the reduction of colorectal cancer risk in those consuming more than 4 cups of coffee per day and in cohort-type studies consuming 5 cups of coffee per day. ${ }^{[26]}$

One of the most discussed types of cancer related to the relationship between coffee and cancer is pancreatic cancer. In a meta-analysis study in which 20 cohort-type studies were evaluated by

Ran et al., ${ }^{[27]}$ high coffee consumption may be associated with decreased pancreatic cancer risk. In a prospective study investigating the effect of coffee consumption on pancreatic cancer, no association was found between caffeine, decaffeinated or total coffee consumption and the risk of pancreatic cancer. ${ }^{[28]}$

\section{TEA}

Tea, produced by processing the leaves of Camellia sinensis, is the most widely used beverage after water worldwide. It is a rich source of pharmacologically active molecules consumed to provide various health benefits. The three main tea forms are green, black and oolong tea, depending on the degree of fermentation. ${ }^{[29]}$

The composition of tea varies according to species, seasons, leaves, climate and horticultural practices. ${ }^{[29]}$ A glass of green tea usually contains $250-350 \mathrm{mg}$ of solids; $30-42 \%$ of it is catechins and $3-6 \%$ is caffeine. ${ }^{[30]}$ Polyphenols are the main active compounds found in teas. Catechins are the main polyphenolic compounds in green tea. ${ }^{[29]}$ Some of these are catechins such as epigallocatechin-3gallate (EGCG), epigallocatechin (EGC), epicatechin3-gallate (ECG) and epicatechin (EC). These polyphenols are found in green tea at much higher concentrations than black or oolong tea and these polyphenols are responsible for the antioxidant properties of tea. ${ }^{[31,32]}$ Among them, EGCG is the most effective and constitutes $50-75 \%$ of catechins. ${ }^{[30]}$ Most of the protective/therapeutic effect of green tea against various types of cancer occurs with EGCG. ${ }^{[33]}$

EGCG has been shown to be potent chemoinhibiting agents in in vitro and in vivo animal models. ${ }^{[34]}$ It has been found that EGCG acts by 
suppressing blood vessel formation (angiogenesis) and regulating its permeability and thus interrupting the feeding of cancerous cells. ${ }^{[3,36]}$

\section{Possible Anticarcinogenic Effects of Camellia Sinensis}

Green tea polyphenols inhibit cell proliferation and show a strong antioxidant activity. ${ }^{[37,38]}$ Polyphenols, especially EGCG, have been found to exhibit antioxidant activity in various mouse organs and thus increase the overall chemoprotective effect of antioxidants in these organs. ${ }^{[39]}$ Polyphenols, especially catechins, can enhance the communication between cells and thus protect cells from tumor development. ${ }^{[40]}$ Experimental studies state that the effects of green tea compounds are by a mechanism that can inhibit tumor growth by closing receptors in the affected cells. ${ }^{[41]}$ Another possible mechanism suggests that EGCG may facilitate direct binding to certain carcinogens. ${ }^{[42]}$ Polyphenols, skin, lung, oral cavity, esophagus, anterior abdomen, stomach, small intestine, colon, liver, pancreas, ovaries and mammary glands, including various organs have been found to help inhibit tumor formation. ${ }^{[43-47]}$ Green tea polyphenols have been shown to induce apoptosis in human lymphoid leukemia cells ${ }^{[48]}$ and human prostate cancer cells. ${ }^{[49]}$

Despite the increasing number of studies revealing the important role of polyphenols as antioxidants with anticarcinogenic properties, the effects of green tea are not yet fully understood. ${ }^{[50]}$

\section{Declaration of conflicting interests}

The author declared no conflicts of interest with respect to the authorship and/or publication of this article.

\section{Funding}

The author received no financial support for the research and/or authorship of this article.

\section{REFERENCES}

1. Bhatti SK, O'Keefe JH, Lavie CJ. Coffee and tea: perks for health and longevity? Curr Opin Clin Nutr Metab Care 2013;16:688-97.

2. Cano-Marquina A, Tarín JJ, Cano A. The impact of coffee on health. Maturitas 2013;75:7-21.

3. Knight CA, Knight I, Mitchell DC, Zepp JE. Beverage caffeine intake in US consumers and subpopulations of interest: estimates from the Share of Intake Panel survey. Food Chem Toxicol 2004;42:1923-30.

4. McCusker RR, Goldberger BA, Cone EJ. Caffeine content of specialty coffees. J Anal Toxicol 2003;27:520-2.

5. Higdon JV, Frei B. Coffee and health: a review of recent human research. Crit Rev Food Sci Nutr 2006;46:101-23.
6. Nawrot P, Jordan S, Eastwood J, Rotstein J, Hugenholtz A, Feeley M. Effects of caffeine on human health. Food Addit Contam 2003;20:1-30.

7. Arab L. Epidemiologic evidence on coffee and cancer. Nutr Cancer 2010;62:271-83.

8. Cornelis MC, El-Sohemy A, Kabagambe EK, Campos H. Coffee, CYP1A2 genotype, and risk of myocardial infarction. JAMA 2006;295:1135-41.

9. Naidoo N, Chen C, Rebello SA, Speer K, Tai ES, Lee J, et al. Cholesterol-raising diterpenes in types of coffee commonly consumed in Singapore, Indonesia and India and associations with blood lipids: a survey and cross sectional study. Nutr J 2011;10:48.

10. Jee SH, He J, Appel LJ, Whelton PK, Suh I, Klag MJ. Coffee consumption and serum lipids: a meta-analysis of randomized controlled clinical trials. Am J Epidemiol 2001;153:353-62.

11. Stalmach A, Mullen W, Nagai C, Crozier A. On-line HPLC analysis of the antioxidant activity of phenolic compounds in brewed, paper-filtered coffee. Braz J Plant Physiol 2006;18:253-62.

12. dos Santos MD, Almeida MC, Lopes NP, de Souza GE. Evaluation of the anti-inflammatory, analgesic and antipyretic activities of the natural polyphenol chlorogenic acid. Biol Pharm Bull 2006;29:2236-40.

13. Bassoli BK, Cassolla P, Borba-Murad GR, Constantin J, Salgueiro-Pagadigorria CL, Bazotte RB, et al. Chlorogenic acid reduces the plasma glucose peak in the oral glucose tolerance test: effects on hepatic glucose release and glycaemia. Cell Biochem Funct 2008;26:320-8.

14. Cornelis MC, El-Sohemy A. Coffee, caffeine, and coronary heart disease. Curr Opin Clin Nutr Metab Care 2007;10:745-51.

15. Bøhn SK, Blomhoff R, Paur I. Coffee and cancer risk, epidemiological evidence, and molecular mechanisms. Mol Nutr Food Res 2014;58:915-30.

16. Surh YJ. Cancer chemoprevention with dietary phytochemicals. Nat Rev Cancer 2003;3:768-80.

17. Mursu J, Voutilainen S, Nurmi T, Alfthan G, Virtanen JK, Rissanen $\mathrm{TH}$, et al. The effects of coffee consumption on lipid peroxidation and plasma total homocysteine concentrations: a clinical trial. Free Radic Biol Med 2005;38:527-34.

18. Yamashita K, Yatsuya H, Muramatsu T, Toyoshima H, Murohara T, Tamakoshi K. Association of coffee consumption with serum adiponectin, leptin, inflammation and metabolic markers in Japanese workers: a cross-sectional study. Nutr Diabetes 2012;2:e33.

19. Crozier TW, Stalmach A, Lean ME, Crozier A. Espresso coffees, caffeine and chlorogenic acid intake: potential health implications. Food Funct 2012;3:30-3.

20. Riksen NP, Smits $P$, Rongen GA. The cardiovascular effects of methylxanthines. Handb Exp Pharmacol 2011;200:413-37.

21. Van't Veer P, Kampman E. Food, nutrition, physical activity, and the prevention of cancer: a global perspective. World Cancer Research Fund/American Institute for Cancer Research; 2007. 
22. Jiang $\mathrm{W}, \mathrm{Wu} \mathrm{Y}$, Jiang $\mathrm{X}$. Coffee and caffeine intake and breast cancer risk: an updated dose-response meta-analysis of 37 published studies. Gynecol Oncol 2013;129:620-9.

23. Simonsson $M$, Söderlind $V$, Henningson $M$, Hjertberg $M$, Rose $C$, Ingvar $C$, et al. Coffee prevents early events in tamoxifen-treated breast cancer patients and modulates hormone receptor status. Cancer Causes Control 2013;24:929-40.

24. Montella M, Polesel J, La Vecchia C, Dal Maso L, Crispo A, Crovatto $M$, et al. Coffee and tea consumption and risk of hepatocellular carcinoma in Italy. Int J Cancer 2007;120:1555-9.

25. Hirose K, Niwa Y, Wakai K, Matsuo K, Nakanishi T, Tajima K. Coffee consumption and the risk of endometrial cancer: Evidence from a case-control study of female hormonerelated cancers in Japan. Cancer Sci 2007;98:411-5.

26. Tian C, Wang W, Hong Z, Zhang X. Coffee consumption and risk of colorectal cancer: a dose-response analysis of observational studies. Cancer Causes Control 2013;24:1265-8.

27 Ran HQ, Wang JZ, Sun CQ. Coffee Consumption and Pancreatic Cancer Risk: An Update Meta-analysis of Cohort Studies. Pak J Med Sci 2016;32:253-9.

28. Guertin KA, Freedman ND, Loftfield E, StolzenbergSolomon RZ, Graubard BI, Sinha R. A prospective study of coffee intake and pancreatic cancer: results from the NIH-AARP Diet and Health Study. Br J Cancer 2015;113:1081-5.

29. Khan N, Mukhtar H. Tea polyphenols for health promotion. Life Sci 2007;81:519-33.

30. Mukhtar H, Ahmad N. Cancer chemoprevention: future holds in multiple agents. Toxicol Appl Pharmacol 1999;158:207-10.

31. Yang CS, Maliakal P, Meng X. Inhibition of carcinogenesis by tea. Annu Rev Pharmacol Toxicol 2002;42:25-54.

32. Yang CS, Wang X, Lu G, Picinich SC. Cancer prevention by tea: animal studies, molecular mechanisms and human relevance. Nat Rev Cancer 2009;9:429-39.

33. Stangl V, Lorenz M, Stangl K. The role of tea and tea flavonoids in cardiovascular health. Mol Nutr Food Res 2006;50:218-28.

34. Liao S, Kao YH, Hiipakka RA. Green tea: biochemical and biological basis for health benefits. Vitam Horm 2001;62:1-94.

35. Demeule M, Michaud-Levesque J, Annabi B, Gingras D, Boivin D, Jodoin J, et al. Green tea catechins as novel antitumor and antiangiogenic compounds. Curr Med Chem Anticancer Agents 2002;2:441-63.
36. Maiti TK, Chatterjee J, Dasgupta S. Effect of green tea polyphenols on angiogenesis induced by an angiogeninlike protein. Biochem Biophys Res Commun 2003;308:64-7.

37. Yang CS, Wang ZY. Tea and cancer. J Natl Cancer Inst 1993;85:1038-49.

38. Yang CS, Lee MJ, Chen L, Yang GY. Polyphenols as inhibitors of carcinogenesis. Environ Health Perspect 1997;105 Suppl 4:971-6.

39. Khan SG, Katiyar SK, Agarwal R, Mukhtar H. Enhancement of antioxidant and phase II enzymes by oral feeding of green tea polyphenols in drinking water to SKH-1 hairless mice: possible role in cancer chemoprevention. Cancer Res 1992;52:4050-2.

40. Sigler K, Ruch RJ. Enhancement of gap junctional intercellular communication in tumor promotertreated cells by components of green tea. Cancer Lett 1993;69:15-9.

41. Komori A, Yatsunami J, Okabe S, Abe S, Hara K, Suganuma $M$, et al. Anticarcinogenic activity of green tea polyphenols. Jpn J Clin Oncol 1993;23:186-90.

42. Hayatsu H, Inada N, Kakutani T, Arimoto S, Negishi T, Mori $\mathrm{K}$, et al. Suppression of genotoxicity of carcinogens by (-)-epigallocatechin gallate. Prev Med 1992;21:370-6.

43. Ahmad N, Mukhtar H. Green tea polyphenols and cancer: biologic mechanisms and practical implications. Nutr Rev 1999;57:78-83.

44. Jankun J, Selman SH, Swiercz R, Skrzypczak-Jankun E. Why drinking green tea could prevent cancer. Nature 1997;387:561.

45. Su LJ, Arab L. Tea consumption and the reduced risk of colon cancer -- results from a national prospective cohort study. Public Health Nutr 2002;5:419-25.

46. Yang CS, Maliakal P, Meng X. Inhibition of carcinogenesis by tea. Annu Rev Pharmacol Toxicol 2002;42:25-54.

47. Zhang $\mathrm{M}$, Binns $\mathrm{CW}$, Lee $\mathrm{AH}$. Tea consumption and ovarian cancer risk: a case-control study in China. Cancer Epidemiol Biomarkers Prev 2002;11:713-8.

48. Hibasami H, Achiwa Y, Fujikawa T, Komiya T. Induction of programmed cell death (apoptosis) in human lymphoid leukemia cells by catechin compounds. Anticancer Res 1996;16:1943-6.

49. Kazi A, Smith DM, Daniel K, Zhong S, Gupta P, Bosley ME, et al. Potential molecular targets of tea polyphenols in human tumor cells: significance in cancer prevention. In Vivo 2002;16:397-403.

50. Boehm K, Borrelli F, Ernst E, Habacher G, Hung SK, Milazzo $S$, et al. Green tea (Camellia sinensis) for the prevention of cancer. Cochrane Database Syst Rev 2009;2009:CD005004. 